\title{
コストに着目した交通調査の精度向上手法の評価*
}

\section{Cost-based Evaluation of Transport Survey Improvement Techniques}

奥村 誠·福住彰規 Makoto OKUMURA, and Akinori FUKGZUMI

\section{1.はじめに}

アンケート方式の交通調查では，精度や回答率が低く なる問題が多く発生し，それを改善する調查手法の開発 が求められている.例えば事前依頼の実施, 調查員教育, コンピュータによる回答負荷の低減, 回答者インセンティ ブ（謝礼）等の方法が考えられるが，これらの改善には 追加的な費用が必要であり，それを精度の向上効果と比 較することが必要である。

本研究では，一定の精度の回答を得るためのコストに 着目することにより, 交通調查の精度改善のための各種 の手法を統一的に比較し，評価する方法を考察する.

以下，2.では回答率や回答精度の向上を目指した手法， 特に回答者インセンティブに関する既存の研究に触れ，本 研究の立場を述べる. 3.では各調査項目の母平均推定量 について，その精度と調查費用との関係を考察し，精度 向上手法の効果を定量化する．4. では直接配布郵送回収 式の交通調查に回答者インセンティブを適用した例を用 い，その効果を実証的に検討する. 最後に 5.では今後の 課題を述べる.

\section{2. 従来の研究と本研究の立場}

\section{(1) 交通調査における無回答問題への対応}

住民等を対象とするアンケート調查は，空間的，時間的 に拡がりを持つ交通行動を把握するための主要な方法と して使用され，定着してきた。最近では，SP調查，CVM 調査などの適用場面も増えている．特に新しい調査では， 細かな行動や意識を尋ねることから回答者の時間的，心 理的負担が大きくなることが多く，回答率や精度が低下 するという問題が発生する.この問題を改善するために， いくつかの方法が考えられる.

例えば，アンケート調查の範囲に限定しても，調查目 的の十分な説明と過去の調查結果の説明，事前依頼の実 施, 調查員教育の徹底, 留置期間中のホットラインの設置 のほか，返送に伴う負担の軽減，電話等を含めた返送方 法の多重化，未回収サンプルへの追加依頼といった方法 が実施されている．これらの方法は主に，調查の意義を アピールし，回答者の意識を喚起し，忘却や紛失を回避

\footnotetext{
* 調查論, 交通行動分析, 意識調査分析, 回答者インセンティブ

†正会員 工博 広島大学工学部 (广 739-8527 東広島市鏡山 1-4-1 Tel\&Fax:0824-24-7827)

士 学生会貝 広島大学大学院国際協力研究科
}

することを目指しているものである.さらに，アンケー トへの回答という作業の時間的，心理的コストに対して， 経済的な補償を行うという考え方に立ち1)，回答者への 金銭的な支払いとして，回答者インセンティブを活用す ることも考えられる。

いずれの方法を採るにせよ，その実施には追加的な費 用が必要であり，それに見合った効果が期待されなけれ ばならない。

\section{(2) 回答者インセンティブに関する従来の研究}

アンケート調査において，インセンティブにより回答率 を高めようという考え方は新しいものではない. Dohrenwend ${ }^{2)}$ 、Feber et al. ${ }^{3)}$ はそれぞれ，複数の種類のインセ ンティブとともにアンケート票を配布し, 回収率に及ぼす 影響を実証的に分析した. その結果，トラベルダイアリー のような複雑な調查では高額のインセンティブをつけた 場合ほど回収率が高くなるが，簡単な調查に過大な謝礼 をつけたり第 2 回目以降に初めてインセンティブをつけ ると，回答率の低下を招くことを指摘している. Bonsal et al. ${ }^{4)}$ はインセンティブの効果は期待するほど大きくな いと報告しており, Richardson et al. ${ }^{5}$ は，わかりやすい 調査票により回答者の時間を節約することが最大のイン センティブになるとし，金銭的インセンティブへの安易 な依存を戒めている.

このように既存の研究ではインセンティブの効果には 否定的な見解が多いが，いずれもその効果を「回答率の 上昇」に限定している. しかし，回答者の母集団が性格の 異なる下位集団（以下では層と呼ぶ）から構成されてい る場合，回答率の上昇が全ての層で一様であるとは限ら ない.もしインセンティブによりもともと回答率の低い 層や標本分散の大きい層の回答率が上昇するならば，費 用の削減効果は大きくなる (A) . さらに, インセンティ ブによって，回答率は同一であっても回答者のアンケー トへの取り組み方が変化し，回答内容が変化する可能性 がある．もし回答の精度が向上し標本分散が小さくなる ならば，所与の精度を確保するための回答数は少なくて も良く, 調査費用の削減が期待できる（B）.

従来の研究は，「回答率の上昇」に限定して効果を捉え ているため，上記のような効果を十分に表現できていな いと考えられる。 


\section{(3) 本研究の立場}

交通調查の精度改善のための種々の手法の具体的な効 果は，小規模なプリ・サーベイを通して明らかにしてい く他はない. 本研究はプリ・サーベイで実施した種々の 手法についてその効果を統一的に評価し, 本調查を効率 化するための適切な手法を選定する方法を提案する. そ の際, 回答率という単純な評価指標ではなく, 各調査項 目の母平均推定量について一定の精度を確保することを 目的と考えて，それを実現するための調查費用の節約額 を用いる.それにより上述した（A）層ごとに回答率の上 昇が一様でない場合や，(B) 回答の標本分散が変化する 場合にも対応できる。

\section{3. 所定の精度を確保する調查費用}

交通調查では 1 枚の調查票で多数の項目を調査し，そ れらを用いてモデルの作成などの定量的な分析を行うの が普通である. 回答者の全員が調查票を返送するわけで はなく，また返送された調査票もすべての項目が回答さ れているわけではない，本来，項目間の関連性を踏まえ た検討を行うことが望ましいが，本研究では各項目ごと の回答を独立して取り扱い, 回答された数值から母集団 平均値を推定する際の精度に絞って議論を行う.

\section{（1）一様な回答率の上昇をもたらす場合}

まず，アンケートの改善手法が母集団全体の回答率を一 様に上昇させるが，回答精度は向上させないケースを取 り上げる. 以下，配布枚数を $m ， 1$ 枚当たりの配布費用 を $C_{x}$, 回答数を $n$, 回答数に比例する処理費用を $C_{o}$ と する. アンケート調査の費用の可変部分 $C$ は,

$$
C=C_{x} m+C_{o} n=\left(\frac{C_{x}}{\bar{e}}+C_{o}\right) n
$$

で表される.ただし， $\bar{e}$ は平均回答率 $(n / m)$ である. 従つ て既存の研究のように, 手法の効果は平均回答率 $\bar{e}$ の上昇 率と配布コスト $C_{x}$ の上昇率との比により判定できる.

\section{（2）回答率と回答精度の一様な上昇がある場合}

いま，着目している項目の標本分散を $s^{2}$ とすると，その 変数の母平均推定量の分散 $\sigma_{\bar{x}}^{2}$ は,

$$
\sigma_{\bar{x}}^{2}=\frac{s^{2}}{n}=\frac{s^{2}}{m \bar{e}}
$$

となる.結果的に分散にして $\sigma_{\bar{x}}^{2}$ だけの精度を確保しよう とすれば, 必要な配布枚数は

$$
m=\frac{s^{2}}{\sigma_{\bar{x}}^{2} \bar{e}}
$$

で表される．これを式 (1) に代入すると，調查の可変費 用は以下のようになる。

$$
C=\left(\frac{C_{x}}{\bar{e}}+C_{o}\right) \frac{s^{2}}{\sigma_{\bar{x}}^{2}}
$$

従って手法の導入による回答率の上昇が大きくなく右辺 （ ）内が増加する場合でも，回答精度が高まり十分に $s^{2}$ が小さくできれば，調查費用を節約できる可能性がある.
（3）回答率の上昇や回答精度の変化がー様でない場合 インセンティブとして何らかの商品を配布する場合，対 象者の性別や年齢などによって効果が異なると考えられ る. 着目する「層」が, 性別のように外見から区別が可 能な属性により定義されている場合には，各層を別々の 母集団と考えた上で式 (4) を適用し，層ごとに配布率を 定め改善手法を適用するかどうかを判断すればよい.

一方，所得のように外見から判断が困難な属性により 「層」が定義されている場合には，全対象者に対して手法 を適用するか否かを一括して検討する必要がある。この 場合, 配布率を層ことに変えることはできないから, 各 層 $i$ の構成比を $R_{i}$ とし, 回収率を $e_{i}$ とすれば, 層 $i$ への 配布数 $m_{i}$ と回収数 $n_{i}$ はそれそれ次のようになる.

$$
m_{i}=m R_{i}, \quad n_{i}=m_{i} e_{i}=m R_{i} e_{i}
$$

対象とする項目の回答について，層こととに平均值が同 じ場合と異なる場合では，集計の際の重みが異なる。

i) 層により平均値が異なる場合

母平均推定量 $\bar{x}=\sum w_{i} x_{i}$ が不偏となるためには各層の重 み $w_{i}$ を回答率 $e_{i}$ に反比例させる必要がある. 各層の回答 の標本分散を $s_{i}^{2}$ とすれば, 母平均推定量の分散は,

$$
\sigma_{\bar{x}}^{2}=\frac{1}{m} \sum\left(\frac{R_{i} s_{i}^{2}}{e_{i}}\right)
$$

となり, 精度の確保に必要な配布枚数および可変費用は 以下のようになる.

$$
\begin{aligned}
& m=\frac{1}{\sigma_{\bar{x}}^{2}} \sum\left(\frac{R_{i} s_{i}^{2}}{e_{i}}\right) \\
& C=\left(\frac{C_{x}}{\bar{e}}+C_{o}\right) \frac{\bar{e}}{\sigma_{\bar{x}}^{2}} \sum\left(\frac{R_{i} s_{i}^{2}}{e_{i}}\right)
\end{aligned}
$$

改善手法の導入前後において, 各層の回答率 $e_{i}$ と標本分散 を $s_{i}^{2}$ を調べ，式 (8) を適用してコストを比較すればよい. ii) 層により平均值が異ならない場合

母平均推定量は重み $w_{i}$ に関わらず不偏となるので，各層 の標本分散に比例する重みを与えることにより，母平均 推定量の分散を最小にすることができる.この時母平均 推定量の分散と配布枚数は,

$$
\begin{gathered}
\sigma_{\bar{x}}^{2}=\frac{1}{m} \frac{1}{\sum\left(\frac{R_{i} e_{i}}{s_{i}^{2}}\right)} \\
m=\frac{1}{\sigma_{\bar{x}}^{2}} \frac{1}{\sum\left(\frac{R_{i} e_{i}}{s_{i}^{2}}\right)}
\end{gathered}
$$

で与えられ，調查の可変費用は次式のようになる.

$$
C=\left(\frac{C_{x}}{\bar{e}}+C_{o}\right) \frac{\bar{e}}{\sigma_{\bar{x}}^{2}} \frac{1}{\sum\left(\frac{R_{i} e_{i}}{s_{i}^{2}}\right)}
$$

式(11) より，ある層の回答率 $e_{i}$ の上昇と標本分散 $s_{i}^{2}$ の低 下は右辺最終項を変化させ調查費用の低隇につながるが， その効果は各層の構成比 $R_{i}$ に依存する.

なお，改善手法の導入により標本平均値がずれる場合に は，母平均の不偏推定量を得ることができなくなる. 従っ てまず，手法の有無間で $\mathrm{t}$ 検定により平均值の同一性を 検定する. 同一性が棄却されなければ, バイアスが生じ 
表-1 インセンティブ別の配布数と回収数

\begin{tabular}{lcccr}
\hline インセンティブ & 配布数 & 回収数 & 回收率 & 単価 \\
\hline (0) な & 798 & 120 & 0.15 & 0 \\
(1) 地 図 & 194 & 31 & 0.16 & 20 \\
(2) 砂 糖 & 103 & 24 & 0.23 & 100 \\
(3) 洗 剤 & 95 & 32 & 0.34 & 200 \\
(4) 図書券 & 98 & 43 & 0.44 & 500 \\
\hline 合 計 & 1288 & 250 & 0.19 & \\
\hline
\end{tabular}

表-2 片道所要時間の回答 1 枚当たりの費用

\begin{tabular}{c|c|cccc}
\hline インセンティブ & $(0)$ & $(1)$ & $(2)$ & $(3)$ & $(4)$ \\
& なし & 地図 & 砂糖 & 洗剤 & 図書券 \\
\hline 回答率 $\bar{e}$ & 0.15 & 0.16 & 0.23 & 0.34 & 0.44 \\
単位配布費用 $C_{x}$ & 133 & 153 & 233 & 333 & 633 \\
$C_{x} / \bar{e}$ & 886 & 959 & 1001 & 1021 & 1443 \\
$C_{x} / \bar{e}$ の比 & 1.00 & 1.08 & 1.13 & 1.15 & 1.63 \\
\hline
\end{tabular}

ていないと判断し，式 (8) または式 (11) を比較し，費用 削減効果を計算すればよい。

\section{4. 実調査データに基づく考察}

大規模な調査を行う際にはプリ・サーベイを実施して 以上の評価を行い，効果的な改善手段を選ぶ必要がある. その方法を例示するため，ここでは事前配布式インセン ティブを活用した小規模な交通調查の実例をとりあげ，以 上の評価を実施して費用節約効果を考察する.

この調查は, 平成 10 年の 5 月, 7 月の休日に，買物、 余㗇活動のために広島市安佐南区古川地区を訪れた人を 対象として実施された非日常的買物行動の調査である. 古 川地区の地図, 砂糖, 洗剂, 図書券の 4 種類のインセン ティブを調查票とともにランダムに配布し，郵送回収を 行った.

なお，回収票に対して事後にインセンティブを送付す れば配布費用 $C_{x}$ の上昇を小さくできるため有利となる可 能性がある．ただし回答者の住所・氏名などを記入させ る必要があり，プライバシーに関わる内容を含む調査に は適用しがたい．また回答者が調查者側の意向に合うよ うに回答を歪める可能性も大きくなる. バイアスの $\mathrm{t}$ 検 定を実施する上記の評価方法は，事後インセンティブの 効果の検討にも利用できるが，以下のケースでは事前イ ンセンティブの効果を検討する.

表-1 に配布数, 回収数, 回収率, インセンティブの単 価を示す. 高額なインセンティブほど回収率も高いが，比 例関係は見られない。なおこの調査では配布時に属性の チェックを行っていないので，3. で用いた各層の構成比 $R_{i}$ を知ることはできない. そこで「インセンティブ無し の場合には各層の回答率が一様であり, $R_{i}$ はインセンティ ブなしの回収数の構成比に等しい」と仮定して以下の計 算を行う.

\section{（1）回収率の向上と費用の変化率}

まず，従来の研究で着目されてきた回収率と費用の変化 に着目する．表-2より，どのインセンティブをつけた場
表-3 インセンティブなしの回答

\begin{tabular}{c|c|c|cc}
\hline 層 & 男性 & 女性 & \multicolumn{2}{|c}{ 2つの層の差 } \\
$R_{i}$ & 0.32 & 0.68 & 検定方法 & 検定結果 \\
\hline 回答率 $e_{i}$ & 0.05 & 0.05 & $R_{i}$ の仮定により同一 \\
平均値 $\bar{x}$ & 0.4 & 0.7 & $\mathrm{t}$ 検定 & 同一 \\
分散 $s_{i}^{2}$ & 0.58 & 0.78 & $\mathrm{~F}$ 検定 & 同一 \\
\hline
\end{tabular}

表-4 地図をつけた場合の回答

\begin{tabular}{|c|c|c|c|c|}
\hline 層 & 男性 & 女性 & \multicolumn{2}{|c|}{ 謝礼なし (表-3) との差 } \\
\hline$R_{i}$ & 0.32 & 0.68 & 検定方法 & 検定結果 \\
\hline 回答率 $e_{i}$ & 0.06 & 0.09 & & \\
\hline 平均值 $\bar{x}$ & 0.5 & 0.5 & $\mathbf{t}$ & 表 3 と同一 \\
\hline 分散 $s_{i}^{2}$ & 0.38 & 0.38 & $\mathrm{~F}$ 検定 & 表 3 と同一 \\
\hline
\end{tabular}

合にも，回収 1 枚当りの費用はインセンティブなしのサ ンプルに比べ大きい。つまり式 (1) に基づく回答率の上 昇のみに着目した考え方では，どのインセンティブも有 効でないと判断される。

2.で述べたように，(A) 層ごとに回答率の上昇が一様 でない場合, (B) 回答の標本分散が変化する場合には, 式 (1) に基づく判断では不十分である. 以下，それそれの ケースを例示する。

\section{（2）回答率上昇の不均一性を考慮した場合 (A)}

(A) 回答率の上昇が層によって異なる例として, 片道所 要時間の回答を取り上げる. まずインセンティブをつけ ない場合に，男性と女性の 2 つの層の標本平均値，標本 分散の同一性をそれぞれ $\mathrm{t}$ 検定， $\mathrm{F}$ 検定で検定した結果 を表-3に示す.これより平均值と分散は 2 つの層で有意 には異ならなかった.インセンティブとして地図をつけ た場合の 2 つの層ごとの平均值，分散は表-4 の通りであ り, $\mathrm{t}$ 検定， $\mathrm{F}$ 検定の結果では表-3に示したケースのそ れらと統計的には同一である.これよりインセンティブ が母集甩平均值にバイアスを発生させないという条件は 満足されている.

式 (11)により, インセンティブ無しの場合と有りの場 合の可変費用を求めると, 前者が $C=2334 / \sigma_{\bar{x}}^{2}$, 後者が $C=1595 / \sigma_{\bar{x}}^{2}$ となり，同一の精度を得るための費用は約 3 分の 2 に節約できる.これは, もともと精度の低い層 （女性）の回収率の向上が大きかったためである.

\section{（3）回答精度の向上がある場合 (B)}

(B) 回答精度の向上が見られた例として，地区外の月訪 問回数の回答を取り上げる．この項目では層ごとの回答 率および分散には差がほとんどなかったため，以下では 層に分けずに検討を行う.

表-5 のように，インセンティブをつけた場合には標本 平均值が若干低下したが， $\mathrm{t}$ 検定では同一性は棄却でき なかった.よってインセンティブによるバイアスは生じ ないという条件は満たされている. 回答率は上昇しなかっ たが, 標本分散が約半分と，有意に小さくなっている.

式 (4)により，インセンティブ無しの場合と有りの場 合の可変費用を求めると, 前者が $C=9037 / \sigma_{\bar{x}}^{2}$, 後者が 
表-5 インセンティブの有無による比較

\begin{tabular}{c|c|c|c}
\hline インセンティブ & $(0)$ なし & $(1)$ 地図 & 差の検定結果 \\
\hline 回答率 $e_{i}$ & 0.15 & 0.15 & 同一 \\
平均値 $\bar{x}$ & 3.0 & 2.4 & 同一 \\
分散 $s_{i}^{2}$ & 7.23 & 3.66 & 異なる \\
\hline
\end{tabular}

表-6 回答項目ごとのインセンティブの効果

\begin{tabular}{|c|c|c|c|c|}
\hline $\begin{array}{c}\text { インセンティブ } \\
\text { 回答項目 }\end{array}$ & $\begin{array}{c}(1) \\
\text { 地図 }\end{array}$ & $\begin{array}{l}(2) \\
\text { 砂糖 }\end{array}$ & $\begin{array}{l}(3) \\
\text { 洗剤 }\end{array}$ & $\begin{array}{c}(4) \\
\text { 园書券 }\end{array}$ \\
\hline \multirow{4}{*}{$\begin{array}{c}\text { 片道所要時間 } \\
\text { 買物時間 } \\
\text { 使用金額 } \\
\text { 同行人数 }\end{array}$} & A & B & $\mathrm{A}, \mathrm{B}$ & $e_{i}>1$ \\
\hline & - & - & - & $e_{i}>1$ \\
\hline & $\begin{array}{ll}- & -1 \\
-1\end{array}$ & - & - & - \\
\hline & - & - & - & - \\
\hline \multirow{6}{*}{$\begin{array}{c}\text { 買物箇所数 } \\
\text { 駐車支払意志額 } \\
\text { 地区外訪問箇所 } \\
\text { 地区外月訪問回数 } \\
\text { 駐車待ち回数 } \\
\text { 駐車待ち時間 }\end{array}$} & - & $\bar{B}$ & - & $e_{i}>1$ \\
\hline & 異平均 & 異平均 & 異平均 & $e_{i}>1$ \\
\hline & - & - & - & - \\
\hline & B & - & - & - \\
\hline & $\mathrm{A}$ & B & - & $\begin{array}{ll}- & \text { r }\end{array}$ \\
\hline & B & 異平均 & B & - \\
\hline
\end{tabular}

$C=4810 / \sigma_{\bar{x}}^{2}$ となり，同一の精度を得るための費用は約 2 分の 1 に節約できることがわかる.

\section{(4) 回答項目ごとのインセンティブの効果}

他の調査項目についても，式 (8),(11) を用いて同様な計 算を行い，インセンティブの有効性を確かめた。表-6で はインセンティブにより費用節約ができるケースにはそ の原因（前述の A,B あるいはその両方）を示し，最も効 率的なものは枠をつけている. 費用が増加してしまうケ一 スには「ー」を表示している。

図書券はどの調查項目に対しても有効とはならなかっ た。これは単位配布費用 $C_{x}$ の上昇率が大きいことによる が，インセンティブ無し回収数の比を基準とする $R_{i}$ を用 い式 (5) により回答率 $e_{i}$ を計算すると, 回答率が 1 を越 えてしまった（表では $e_{i}>1$ と表示）ケースも多かった. インセンティブによるバイアス（標本平均値の変化）は ほとんど見られなかったが，駐車支払意志額では有意な 差が検出され（表では「異平均」と表示），SP 調查項目 ではインセンティブによりバイアスが発生する可能性が 高いと推察される.もちろん, もともと存在するバイア スがインセンティブにより除去できた，という逆の可能 性もあるため, 標本分散の変化を踏まえた綿密な検討を
行うことが必要である。

表一 6 より，地図、砂糖、洗剂をつけることで費用節 約ができる場合があるが，どの調查項目に対して有効か は異なり，一概にどのインセンティブが有利とは言えな い. 従って今回の調査のようなプリ・サーベイを実施し， 重視する回答項目に応じて最適なインセンティブの種類 を選ぶことが望まれる。

\section{5. おわりに}

本研究では, アンケート調查の精度改善手法の効果を, 精度と費用の関係式 (8),(11) により統一的に評価する方 法を提案した. さらに回答者インセンティブを取り入れ た交通調査を例に，回収率の平均的な向上が調查費用の 増加分を上回らないようなケースでも，層ごとの回収率 の向上が不均一であることや精度の向上効果を考慮して 評価することにより，インセンティブの導入が効率的に なることを示した. 最後に今後の課題を述べる.

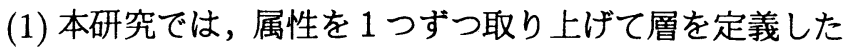
が，いくつかの属性を組み合わせて層別を行う場合の検 討を行う必要がある.

(2) 本研究では、調查項目ごとに母平均推定量の精度を考 えてきた.今後は複数の調查項目を用いてモデルを構築 することを想定し，モデルの誤差を小さくするインセン ティブについて検討する必要がある。

\section{参考文献}

1) Philipson, T.: Data Markets and the Production of Sur veys, Review of Economic Studies, 64,73-96,1997.

2) Dohrenwend, B.S.: An experimental study of payments to respondents, Public Opinion Quarterly, 34, 621-624, 1970.

3) Feber,R. and Sudman,S. : Effects of compensation in consumer expenditure studies, Annals of Economic and Social Measurement, 3(2), 319-331, 1974.

4) Bonsall,P.W. and McKimm,J.:Non-response bias in roadside mailback surveys, Traffic Engineering and Control, December,582-591,1993.

5) Richardson, A.J., Ampt E.S. and Meyburg,A.H.: Survey Methods for Transport Planning, Eucalyptus Press, 243246, 1995.

\section{コストに着目した交通調査の精度向上手法の評価}

奥村 誠 ・ 福住彰規 交通調查において, 細かな行動や意識などを含む複雑な調查が増え, 精度や回答率が低くなる問題点が指摘されている. 本研究は，この問題に対処するための各種の改善手法の効果を所定の精度を確保するための費用を用いて統一的に評価 する手法を提案する.さらに, 回答者へのインセンティブ（謝礼）の精度向上効果を例に, 評価手法の適用例を示す.

\section{Cost-based Evaluation of Transport Survey Improvement Techniques}

Makoto OKUMURA, and Akinori FUKUZUMI

Besides respondent incentive articles (RIA), there are many possible measures to increase response rate and improve accuracy in transport survey. This study proposes that performance of those measures can be evaluated based on the survey cost which satisfies given accuracy level. The proposed criteria can be applied for the technique which alter the response rate or accuracy unevenly for seleral sub-groups of the population. A case study of a shopping travel survey held in a shopping district in Hiroshima City practically illustrates the effectiveness of the RIAs, based on the proposed criteria. 